Article

\title{
Least Cost Analysis for Biocorrosion Mitigation Strategies in Concrete Sewers
}

\author{
Georgios Fytianos ${ }^{1, *(\mathbb{C}, \text { Emmanouil Tziolas }}{ }^{2}$, Efthimios Papastergiadis ${ }^{1}$ and Petros Samaras ${ }^{1}$ (1) \\ 1 Department of Food Science and Technology, International Hellenic University, Sindos, 57400 Thessaloniki, \\ Greece; efspa@food.teithe.gr (E.P.); samaras@food.teithe.gr (P.S.) \\ 2 ELGO-Demeter, Fisheries Research Institute, 64007 Nea Peramos, Kavála, Greece; tziolasm@inale.gr \\ * Correspondence: gfytianos@gmail.com; Tel.: +30-2310013355
}

Received: 15 May 2020; Accepted: 2 June 2020; Published: 4 June 2020

\begin{abstract}
The changing role of the municipal water and wastewater authorities, together with the need for a sustainable maintenance treatment in the sewer systems, have been the catalysts for the integration of technical and financial information into asset management systems. This paper presents results from a cost-comparative analysis focusing on an annuities calculation for the evaluation of microbiologically induced corrosion (MIC) or biocorrosion mitigation methodologies used in the maintenance of concrete sewers. The replacement cost of deteriorated sewer concrete pipes is high, and MIC mitigation methods can be used to increase the current service life of concrete pipes. From the MIC mitigation methods that are frequently used, the authors examined those of flushing with high-pressure water (i.e., a common method used in Greece), and spraying with magnesium hydroxide slurry (MHS). The authors chose four different cities for the assessment, which presented different sewer characteristics and socioeconomic backgrounds. In addition, all methods for concrete sewer MIC mitigation were compared to the present value of replacement of sewer concrete pipes with new PVC ones. Results showed that flushing with high-pressure water is very cost demanding and should be avoided, while spraying with MHS could be a sustainable and economic solution in the long term.
\end{abstract}

Keywords: sewer corrosion; least cost analysis; biocorrosion

\section{Introduction}

Microbiologically induced corrosion (MIC) or biocorrosion in concrete sewers is a known problem [1]. The root cause of MIC is the formation of $\mathrm{H}_{2} \mathrm{~S}$, which is produced from sulfates in wastewater under a reaction with sulfate-reducing bacteria located in a slime layer. $\mathrm{H}_{2} \mathrm{~S}$ can be oxidized to $\mathrm{H}_{2} \mathrm{SO}_{4}$, due to the presence of sulfur-oxidizing bacteria, which rapidly corrodes the concrete in sewer pipes. In a concrete sewer wherever there is an adequate $\mathrm{H}_{2} \mathrm{~S}$ gas $(>2 \mathrm{mg} / \mathrm{L})$, high relative humidity, and high atmospheric oxygen content, MIC can take place. These conditions are thought to exist in the majority of wastewater systems for at least some times during the year [2]. Worldwide, the economic losses due to MIC are very high [3]. Annual rehabilitation costs were estimated to reach over USD 400 million in Germany and over USD 100 million in the United Kingdom [4]. In Flanders, Belgium, biocorrosion related costs are approximately $10 \%$ of the total sewage treatment cost [5]. Worldwide, it is difficult for municipalities to repair old and deteriorated concrete sewers since sometimes sewers are under historic and populated places [6].

Concrete is still the most used material for sewer pipes in Greece, while for newly installed sewer systems, PVC pipes are favored due to their better corrosion resistance properties and lower price. In Greece there is no systematic monitoring and research on biocorrosion, and based on a recent survey, the local directors of sewerage treatment enterprises are willing to try new MIC mitigation strategies [7]. 
So far, in study cases in Greece the presence of $\mathrm{H}_{2} \mathrm{~S}$ in sewers has mainly been addressed with a focus on odor management [8].

Several studies have implemented a life cycle assessment (LCA) methodological approach to assess sewage treatment plants $[9,10]$ and wastewater treatment plants [11,12], while the perspective of these assessments is biased towards the treatment's operational stage. Many related studies take into account the construction phase, apart from the operational stage, which is responsible for only $20 \%$ or less of the total environmental impacts [13], though a significant number of studies dwell on the pipe materials $[14,15]$. Nevertheless, in the abovementioned assessments of sewage and wastewater treatment plants, the maintenance and repair aspect of deteriorating concrete is neglected. The poor durability of these constructions will enhance negative impacts to human health and the infrastructure, while time will spread the impacts to several parts of the infrastructures and aggravate the plants' stability [16] with significant economic impacts [17].

Regarding the pure economic cost of sewer rehabilitation and/or repair-maintenance alternatives, several aspects (e.g., discounting factor, inflation rate, investment period etc.) could create significant trade-offs among the alternatives. More specifically, ÆEsøy et al. [17] have stated the immense cost fluctuation of different projects across the whole world caused by different intervention strategies and different periods of time. Furthermore, a more recent study illustrates that the replacement cost for a relevant project accounts for more than $50 \%$ of the total investment cost [18], highlighting the need for a cost-efficient long-term strategy in a centralized system. The evaluation of alternatives could be done based on an annuities calculation and the depiction of costs in the form of a net present value (NPV), following a solid perspective for the right choice in the rehabilitation of sewers [19]. The operations of treatment and disposal of sewage sludge accounts for approximately $40 \%$ to $50 \%$ of the total operational costs of a wastewater treatment plant [20]. Focusing on the distribution of costs in wastewater systems, the maintenance aspect accounts for more than one fourth of the total costs [21], whilst specifically in concrete pipes the costs are dependent on the interaction between the discount and inflation rate [22]. Therefore, there is a significant cost connected to the repair and maintenance actions taken. In this context, the management of operational actions related to sewer networks is multi-faceted and requires the investigation of economic and environmental consequences as well [23].

Focusing on Greece, the changing role of the local Municipal Water and Sewerage Enterprises (MWSE in this paper, $\triangle \mathrm{E}$ YA in Greek) together with the need for a sustainable maintenance treatment in the sewer systems, has been the catalyst for the integration of technical and financial information into asset management systems. Thus, the application of least cost analysis to sewer installation and maintenance projects has increased in recent years [24]. MWSEs, due to the limitations in their budget, need to include some type of financial analysis for their corrosion maintenance process.

Economic data is more tangible, and can be exported at any time with ease through various methods of qualitative and quantitative research. Unlike information related to air pollutant emissions, that require ideal conditions and expensive equipment to measure, financial data is more easily accessible and can also be targeted to selected areas. The development of a financial assessment for the investigation of economic impacts related to corrosion controlling methods will formulate the main perspective of the present research. In this context, a focus on the design and management of maintenance for the existing structures is given [25], while calculating the manifold impacts for every corrosion controlling method. To further expand upon this, there is a necessity for the economic assessment of the current sewer system in Thessaloniki, Serres, Kozani, and Florina based on the survey of Fytianos et al. [7]. Thessaloniki, as a capital of Northern Greece, should have higher social impacts due to maintenance in the city center, while Kozani and Florina should have difficulties with relevance to the cleaning process due to the smaller pipe sizes. Therefore, given the set boundaries, the economic aspects for each controlling method in the four cities are highlighted, since the local characteristics should be carefully considered because they could affect the total annual costs [26]. In addition, the corrosion mitigation methods' net present values costs are compared to the replacement cost of sewer concrete pipes with new PVC ones. 
The objective of this paper is to investigate the future cost of MIC mitigation strategies and to provide the optimized solution for each case. To this end, the authors developed a cost-comparative framework, based on net present value (NPV), as a basic research tool. The different mitigation strategies can be categorized into three groups $[3,27,28]$; (i) proper sewer hydraulic design, (ii) concrete performance improvement, (iii) and altering sewer pipe environment. This paper focuses on the mitigation strategies for the already installed concrete sewers. Therefore, the MIC mitigation strategies that will be examined focused on altering the sewer pipe environment i.e., controlling the sulfide production.

\section{Materials and Methods}

\subsection{MIC Mitigation Methods}

From the MIC mitigation methods that are frequently used, the authors examined those of flushing with high-pressure water (i.e., a common method used in Greece) and spraying with magnesium hydroxide slurry (MHS). MHS has been used successfully for the corrosion control of concrete sewers [29].

\subsubsection{Flushing with High-Pressure Water}

The use of high-pressure water for flushing the concrete surface has been studied [30,31]. Although flushing with high-pressure water removes the corrosion deposits from the concrete surface and increases the surface $\mathrm{pH}$, the effects are short term, i.e., from 2 weeks [30] to $2-4$ months [31], and for long term protection, frequent flushing with high-pressure water is necessary. In the current work, the authors used a monthly frequency scenario for high-pressure water flushing of concrete pipes.

\subsubsection{MHS Spraying}

Compared to other chemical treatment methods, spraying with MHS is considered to be a very cost-effective methodology [29], which can add additional years of service life to a concrete sewer. MHS will raise the concrete wall's $\mathrm{pH}$ to around 9.5. If an adhesion additive is used in the mix, since MHS has very low solubility in water, it can stay on the concrete for sufficient time. An ongoing national R\&D project led by Grecian Magnesite S.A. [32] focuses on the development of a product, based on $\mathrm{Mg}(\mathrm{OH})_{2}$ and $\mathrm{MgO}$, for the coating of the inner surfaces of concrete sewer network pipes with corrosion problems. In this paper, the authors examined the case of one spraying of MHS per year. For the application area of a magnesium hydroxide coating (MHC) by spraying, the area of the inner concrete pipe is calculated as:

$$
\text { Pipe Surface }=2 \pi \mathrm{rh}
$$

where $r$ is the radius of each sewer pipe and $h$ is the length. The volume of MHC that would be needed can be calculated as:

$$
\mathrm{V}_{\mathrm{MHC}}\left[\mathrm{m}^{3}\right]=\text { Pipe surface }\left[\mathrm{m}^{2}\right] \times \text { MHC thickness }[\mathrm{m}]
$$

where MHC thickness is estimated at $0.005 \mathrm{~m}$. The mass of the needed MHC is calculated as:

$$
\mathrm{m}_{\mathrm{MHC}}[\mathrm{kg}]=\rho_{\mathrm{MHC}}\left[\mathrm{kg} / \mathrm{m}^{3}\right] \times \mathrm{V}_{\mathrm{MHC}}\left[\mathrm{m}^{3}\right]
$$

where $\rho_{\mathrm{MHC}}=1500 \mathrm{~kg} / \mathrm{m}^{3}$.

For example, (Figure 1) for a pipe of $1 \mathrm{~m}$ length and $1 \mathrm{~m}$ diameter the pipe surface would be equal to $3.141 \mathrm{~m}^{2}$, and from Equation (2), the $\mathrm{V}_{\mathrm{MHC}}$ that would be needed is equal to $0.0157 \mathrm{~m}^{3}$. The corresponding $\mathrm{m}_{\mathrm{MHC}}$, from Equation (3) is equal to $23.55 \mathrm{~kg}$. 


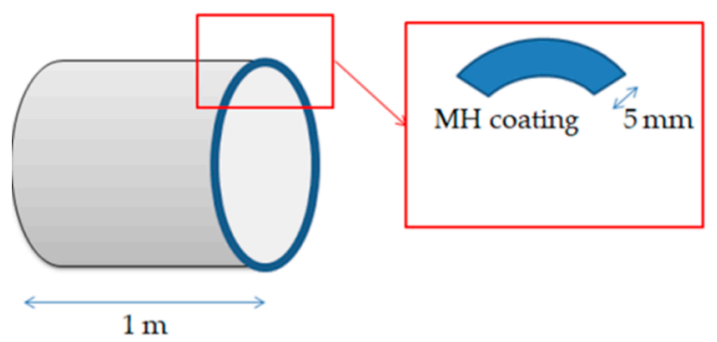

Figure 1. Schematic representation of the magnesium hydroxide coating $(\mathrm{MHC})$ in a sewer pipe.

\subsection{Cost-Comparative Analysis}

The entire initial analysis of the methodology and the parameters to be studied are presented in detail by $[19,33]$. Consequently, this paper's insight includes the least cost analysis framework assessment for the sewage system and all the relevant actions included in the maintenance and repair stage for controlling corrosion. The current framework is multilateral and contains a step by step evaluation regarding economic and social extensions, while providing rational conclusions. Hence, the system boundaries will be depicted together with the goals of the approach similar to the LCA perspective. Next in order will be the inventory analysis, and in continuation the formulas for the economic assessment will be illustrated, in order to proceed to the results section.

\subsubsection{Goal and Scope Definition}

The main aim of this paper is to investigate the costs of maintenance via two MIC mitigation strategies and to provide recommendations for each case, based on a least cost analysis methodological framework. The system boundaries were set to a fifty-year continuous procedure of maintenance via a net present value (NPV) formula for every mitigation strategy, while PVC installation is also considered as a third option. The economic system is included in the social and natural system. In the latter, it is not possible to record the external influences that come in and out of the system, as it is most likely that they cannot be easily quantified (e.g., disturbance cost which is a social impact). Therefore, the system is divided into two parts, in which the primary section represents the internal costs, as recognized by [34] and the secondary section illustrates external costs in the form of delay due to the intervention of maintenance [33] (Figure 2).

Regarding the functional unit of the relevant system, it is usually set to flow rate of sewage (effluent), though the length or the weight of sewer pipeline is a usually implemented functional unit for similar studies [15]. Due to insufficient data for the flow rate for every town, $1 \mathrm{~km}$ of implemented maintenance actions is utilized in this study. Furthermore, the current format is used because the assessment is strictly targeted to the actions of maintenance, and not to the whole project design and operation stage of the sewerage network. Finally, the quantity of inputs differs based on the pipe's size, as well as the amount of labor hours and machinery depreciation. Given that, an inventory is formulated with all the relevant inputs and assumptions of this research. 


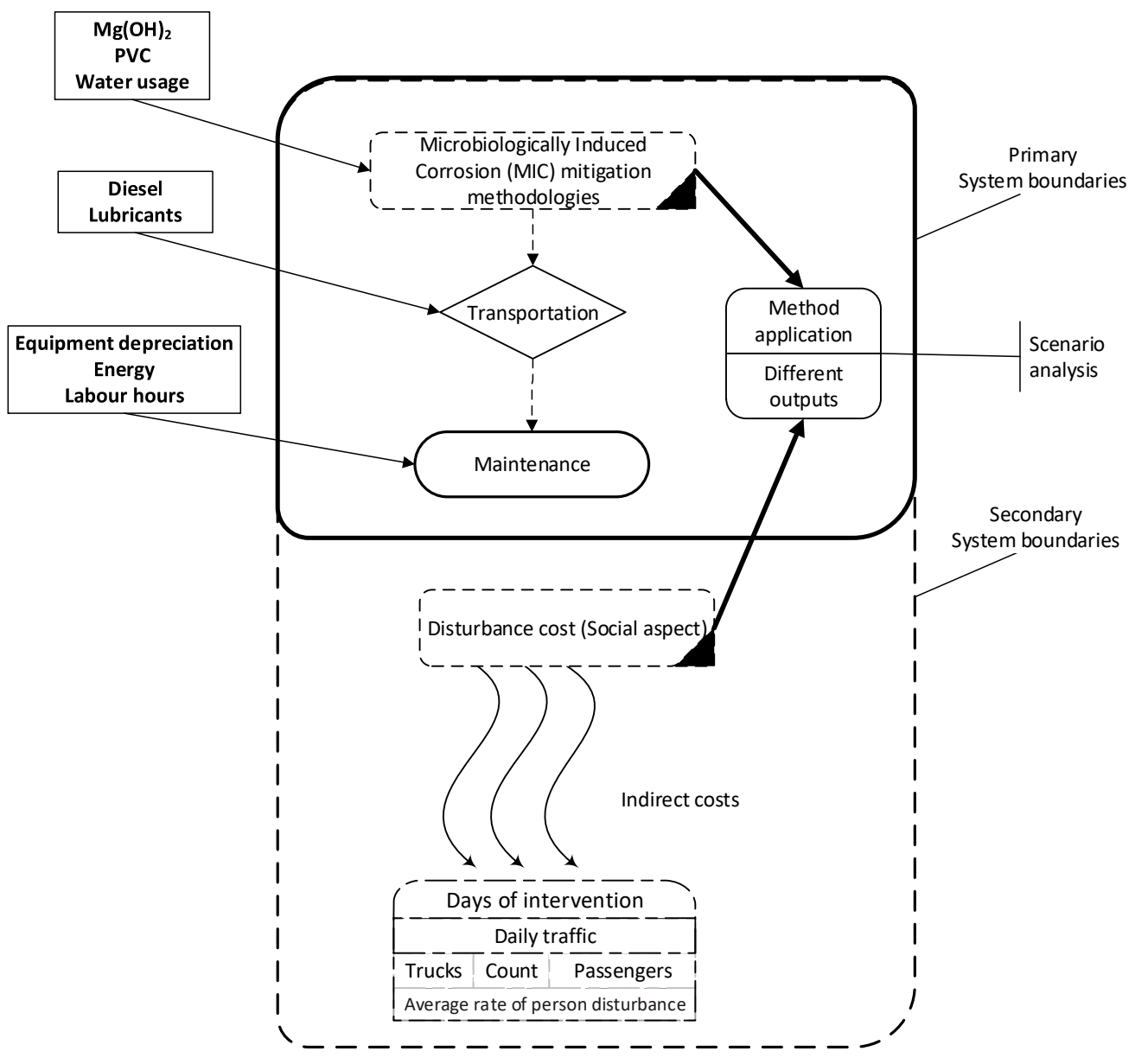

Figure 2. System Boundaries.

\subsubsection{Inventory Analysis}

The formation of an inventory is a complicated procedure which demands analytical depiction of the designated goals and data. In comparison to an LCA inventory, the tangible aspect of economic datasheets develops an easily understandable environment for our approach, from which the final results can be interpreted without difficulty. This signifies the importance of least cost analysis in a system of controlling corrosion methods, which is mostly based on activities (maintenance and repair), and to a lesser degree on the production of solid materials (e.g., the construction phase).

More specifically, costs are divided into different driving forces (e.g., hours of work, number of employees, amount of consumables, etc.) and then classified into different cost categories (e.g., EUR/labor hour, EUR/mechanical labor, EUR/worksheet, etc.). The inventory is enriched with data from field measurements [7], whilst specific coefficients are taken from official records (e.g., euros per hour of labor). Furthermore, valid assumptions—based on the primary data-should be made, in order to have credible results.

In conjunction with the abovementioned, an inventory analysis is depicted in Table 1. Several assumptions have been made in relation to the radius of the maintenance interventions. Specifically, in Thessaloniki the radius was set to $50 \mathrm{~km}$, in Serres to $30 \mathrm{~km}$, and in Kozani and Florina to $20 \mathrm{~km}$, based on the region's size. The economic life of the maintenance intervention was set to 50 years, since the service life of PVC as sewer material has a maximum of 50 years [33]. The prices for PVC installations were taken from a national restricted call for tenders in the Greek region. Finally, all the other values have been obtained from specific references and/or current prices from the Greek territory. 
Table 1. Inventory analysis.

\begin{tabular}{|c|c|c|c|}
\hline Assumptions & Unit & Values & Remarks \\
\hline Area radius & $\mathrm{km}$ & $20-50$ & Different scenarios based on city size \\
\hline Expected economic life & $\mathrm{yr}$ & 50 & [19] \\
\hline \multicolumn{4}{|l|}{ Inputs } \\
\hline Labour & $€ / \mathrm{h}$ & 6.33 & National payscale \\
\hline Water consumption & $€ / \mathrm{m}^{3}$ & $0.95-1.11$ & $\begin{array}{l}\text { Based on the selling price of each } \\
\text { MWSE }\end{array}$ \\
\hline $\mathrm{Mg}(\mathrm{OH})_{2}$ Slurry & $€ / \mathrm{m}$ & $2.65-10.60$ & Based on the sewer diameter \\
\hline Diesel & $€ / 1$ & 1.5 & \\
\hline Lubricants & $€ / 1$ & 3.275 & $7 \%$ of diesel \\
\hline Energy & $€ / \mathrm{kWh}$ & 0.13001 & National electricity price \\
\hline \multicolumn{4}{|l|}{ Outputs } \\
\hline $\begin{array}{l}\text { NPV for each corrosion } \\
\text { mitigation strategy }\end{array}$ & $€ / \mathrm{km}$ & & Figures $3-5$ \\
\hline $\begin{array}{l}\text { PVC replacement } \\
\text { Equipment depreciation }\end{array}$ & $€ / \mathrm{km}$ & $361,567-569,320$ & Based on the Concrete Pipe Size \\
\hline Sprayer & $€ / \mathrm{h}$ & 1.26 & $\begin{array}{l}\text { ABC software } \\
\text { http://www.abc.aua.gr/ }\end{array}$ \\
\hline Lorry $2 \mathrm{~T}$ & $€ / h$ & 10.86 & $\begin{array}{l}\text { ABC software } \\
\text { http://www.abc.aua.gr/ }\end{array}$ \\
\hline \multicolumn{4}{|c|}{ Disturbance (Indirect impacts) } \\
\hline Annual daily traffic & Vehicles/day & $236-4128$ & {$[35]$} \\
\hline Time delay & $\mathrm{h}$ & $0.15-0.5$ & Based on the controlling method \\
\hline Days of each project & days & - & Based on the duration \\
\hline Person labor hour & $€ / \mathrm{h}$ & 6.33 & National payscale \\
\hline Freight delay & $€ / h$ & 17.97 & National payscale \\
\hline Vehicle passenger traffic & $\%$ & 97 & [33] \\
\hline Vehicle freight traffic & $\%$ & 3 & [33] \\
\hline Occupancy of vehicle & Persons & 1.2 & [33] \\
\hline
\end{tabular}

\subsubsection{Economic Assessment Formulas}

Several costs in relation to acquisition, energy consumption, maintenance, operation, end of life costs, and various other costs over the life cycle of a product and/or service should be considered. In this context, this methodological framework accounting for all these relevant costs of a product or an activity is discounted over its life existence. Accounting the costs for a sewer system is based on a simple equation for each activity $i$, aggregating different amounts of costs (CC: Cumulative Costs) $[21,22,36]$ :

$$
C C=C_{i n i}+C_{o p}+C_{m}+C_{e n}+C_{i n d}-C_{r v}
$$

where $C_{\text {ini }}$ represents the initial costs of commissioning, purchasing, and installing inputs. $C_{o p}$ depicts the operation costs, $C_{m}$ the maintenance costs, $C_{e n}$ the energy costs, and $C_{r v}$ the residual value of the investment. Regarding $C_{i n d}$, there are several indirect costs included in a construction project such as environmental, social, downtime, and decommissioning costs. In order to untangle the cost of a project over its lifetime, specific future costs should be depicted in equivalent values of today. Furthermore, replacement costs are represented as onetime actions, while others like maintenance costs are more frequent. This is where the present value (PV) is introduced, based on equivalent costs of actions at a current or present time. Consequently, this would be the amount of money that should be set aside today, in order to face future costs of the desired design project. The PV calculation is illustrated below:

$$
P V=\frac{F V}{(1+r)^{n}}
$$

where $F V$ is the future value, $r$ is the rate of return, and $n$ is the number of periods. When compounding the inflation/interest rate, a general formula is illustrated for drainage projects by the Concrete Pipe Association of Australasia (ACPA) [33] as presented below: 


$$
F C=P C(1+I)^{n}
$$

or

$$
P C=F C(1+i)^{n}
$$

where $F C$ is the future cost, $P C$ is the present cost, $i$ is the interest rate, $I$ is the inflation rate, and $n$ is the number of periods. Usual maintenance actions for concrete sewers include the removal of debris, silt removal, flushing, and the repair of damage. For this research focus is given to the maintenance actions in relation to the MIC in concrete sewers. This includes two different maintenance actions, namely flushing with high-pressure water, and spraying of MHS. The maintenance cost equation is calculated below, according to ACPA [33], based on the durability variation of the applicable products:

$$
M C=A_{m c} \frac{1-F^{n}}{\frac{1}{F}-1}
$$

where $M C$ represents the maintenance cost, $A_{m c}$ is the annual maintenance cost and $n$ is the years of service life. The value $F$ depicts the interaction between the inflation and the discount rate as illustrated below:

$$
F=\left(\frac{1+I}{1+i}\right)^{n}
$$

Apart from the direct economic impacts due to sewer maintenance, there are also indirect impacts as mentioned before. The economic impact due to disturbances during road closures is calculated as a secondary part of this research, since it could be a significant cost to the social life of an area. Within this framework the disturbance formula is integrated and is presented below [33]:

$$
\text { Disturbance cost }=A A D T * t_{h} * d_{p} *\left(c_{v h} * v_{v} * v_{o f}+c_{f h} * v_{f}\right)
$$

where

$A A D T=$ annual average daily traffic of the relevant roadway

$t_{h}=$ average increase in delay in hours for every vehicle per day

$d_{p}=$ number of days the project will take

$c_{v h}=$ average rate of person-labor hour, in euros per hour

$v_{v}=$ percentage of passenger vehicles traffic

$v_{\text {of }}=$ vehicle occupancy factor

$c_{f h}=$ average rate of freight-delay, in euros per hour

$v_{f}=$ percentage of truck traffic

\section{Results}

The cities of the case studies are presented in Table 2. More specifically, Thessaloniki is the second largest metropolis in Greece, which plays a significant role in the Balkan region as a trade center. Serres and Kozani share the same statistics in population and Florina is the smallest of all with many disadvantaged areas due to the high altitude. This creates an uneven situation among them regarding the deterioration of their sewer system, inducing manifold problems due to different needs. In Table 2, the "Peak Population Equivalent" data was taken by the monitoring database of the special secretariat for water, Ministry of Environment and Energy [37]. In addition, in Table 2, a combined system is a system which carries both surface run-off and wastewater, while a separate system carries the municipal wastewater and surface run-off separately. The concrete pipe size of Table 2 is one of the main sewer diameters of each city. 
Table 2. Details of case study cities.

\begin{tabular}{ccccc}
\hline Town & $\begin{array}{c}\text { Town Number on } \\
\text { Map }\end{array}$ & $\begin{array}{c}\text { Peak Population } \\
\text { Equivalent }\end{array}$ & Type of System & Concrete Pipe Size \\
\hline Thessaloniki & 1 & 900,000 & Combined & $1000 \mathrm{~mm}$ \\
Serres & 2 & 79,000 & Combined & $800 \mathrm{~mm}$ \\
Kozani & 3 & 46,000 & Combined & $250 \mathrm{~mm}$ \\
Florina & 4 & 20,000 & Separate & $400 \mathrm{~mm}$ \\
\hline
\end{tabular}

In Figure 3, the accumulated costs for all cities for 50 years of corrosion prevention strategies are presented. The current inflation rate of Greece is integrated, which is $0.9 \%$, while for the discount rate the European recommendation (Commission Recommendation (EU) 2019/1659) for a social discount rate in economic analysis (3\%) is followed. The major difference in Figure 3 is the depiction of costs in a chronological order. Although the maintenance costs of MHS and water flushing are presented in PV form through time, the cost of PVC installation is depicted as a one-time investment cost. This classification has been made due to the permanent character of PVC installations in comparison to mitigation methodologies used in the maintenance of concrete sewers, which should take place many times in the years to come. In this manner, the significance of the decision-making regarding the right option between biocorrosion mitigation techniques could be illustrated. If the selected option is PVC, then the right time to proceed with the current project is as soon as possible, since the costs will increase drastically.
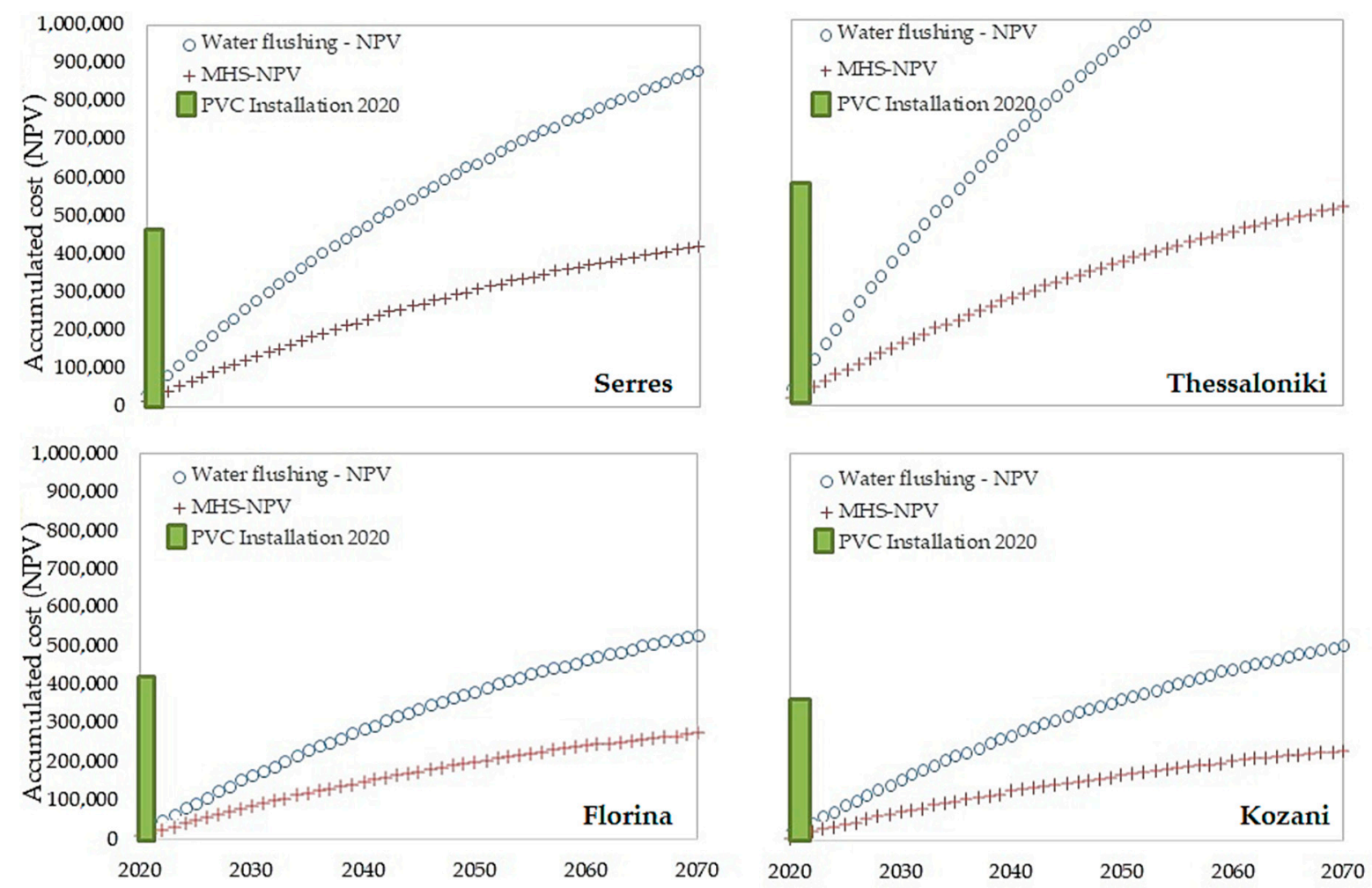

Figure 3. Accumulated costs for 50 years' corrosion prevention strategies.

On the other hand, for a short term strategy, the application of MHS and even water flushing (for a very short period) is a much more attractive investment for the MWSEs. In Kozani, the accumulated costs for a 50-year corrosion prevention strategy plan for concrete pipes with diameter $250 \mathrm{~mm}$ are presented. It can be observed that MHS spraying is the best option. The value of water flushing, although much more costly compared to MHS, is less expensive compared to the new PVC installation in Kozani, a middle-sized town of 150,000 residents which is experiencing concrete biocorrosion 
problems [7], and where the local MWSE is using high-pressure water flushing as a biocorrosion mitigation technique. In the study case of Florina, the results showed similar trends to those of Kozani.

However, in the cases of Serres and Thessaloniki, the high-pressure water flushing is the worst option, while MHS spraying seems the most sustainable plan. After 25 years in Serres and after 20 years in Thessaloniki, the net present value of high-pressure water flushing is shown to reach the PVC installation present costs. These results can be explained by the following reasons: (i) the amount of maintenance labor hours in Thessaloniki is much higher compared to the cities, (ii) Thessaloniki has the largest pipe diameters among the cities and that makes water-flushing the most expensive method of all.

In Figures 4 and 5 the NPV graphs for 50 years' use of high-pressure water flushing and for the application of MHC onto sewer pipes are presented accordingly, with a small alteration to the inflation rates. Greece faced severe economic uncertainty from 2008 onwards, with financial indicators constantly changing. Deflation has had a significant impact on the Greek economy, with continuously falling prices and decreasing consumption. While the country still tries to overcome economic obstacles, the inflation rate (IR) is noticeably lower than the average inflation rate in the EU. Therefore, the inflation rate will increase in the years to come, since the simulations follow this trend, and the authors have taken this into consideration. IRs of $0.9 \%$ and $1.6 \%$ are plotted, as $1.6 \%$ is considered as an EU average. When it comes to the use of high-pressure water, it can be observed that in the case of IR $1.6 \%$, installing PVC sewer pipes is currently a more cost-efficient decision than using high-pressure water for 50 years.

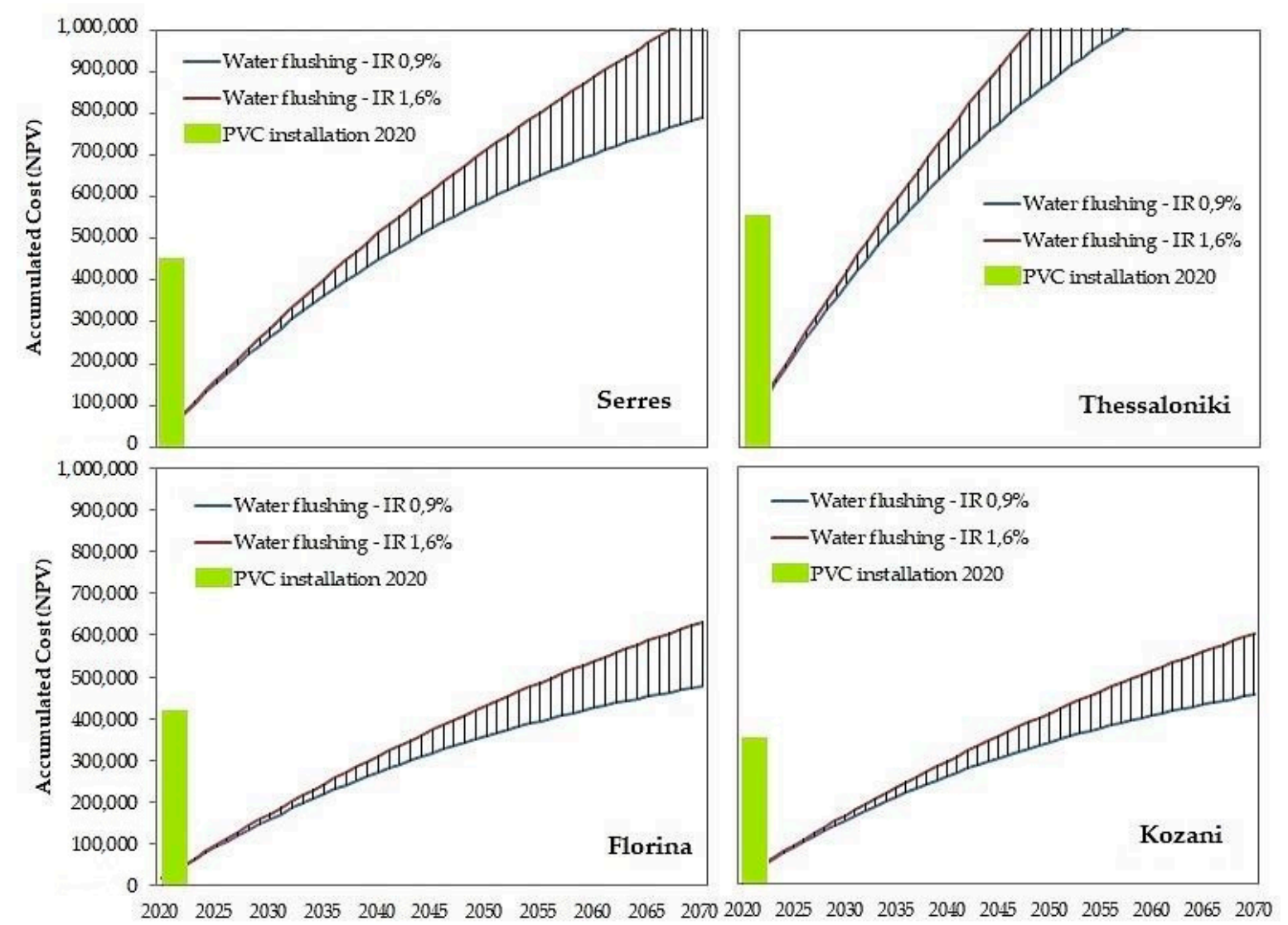

Figure 4. Net present value (NPV) graphs for high-pressure water flushing for 50 years for inflation rates (IR) $0.9 \%$ and $1.6 \%$. 

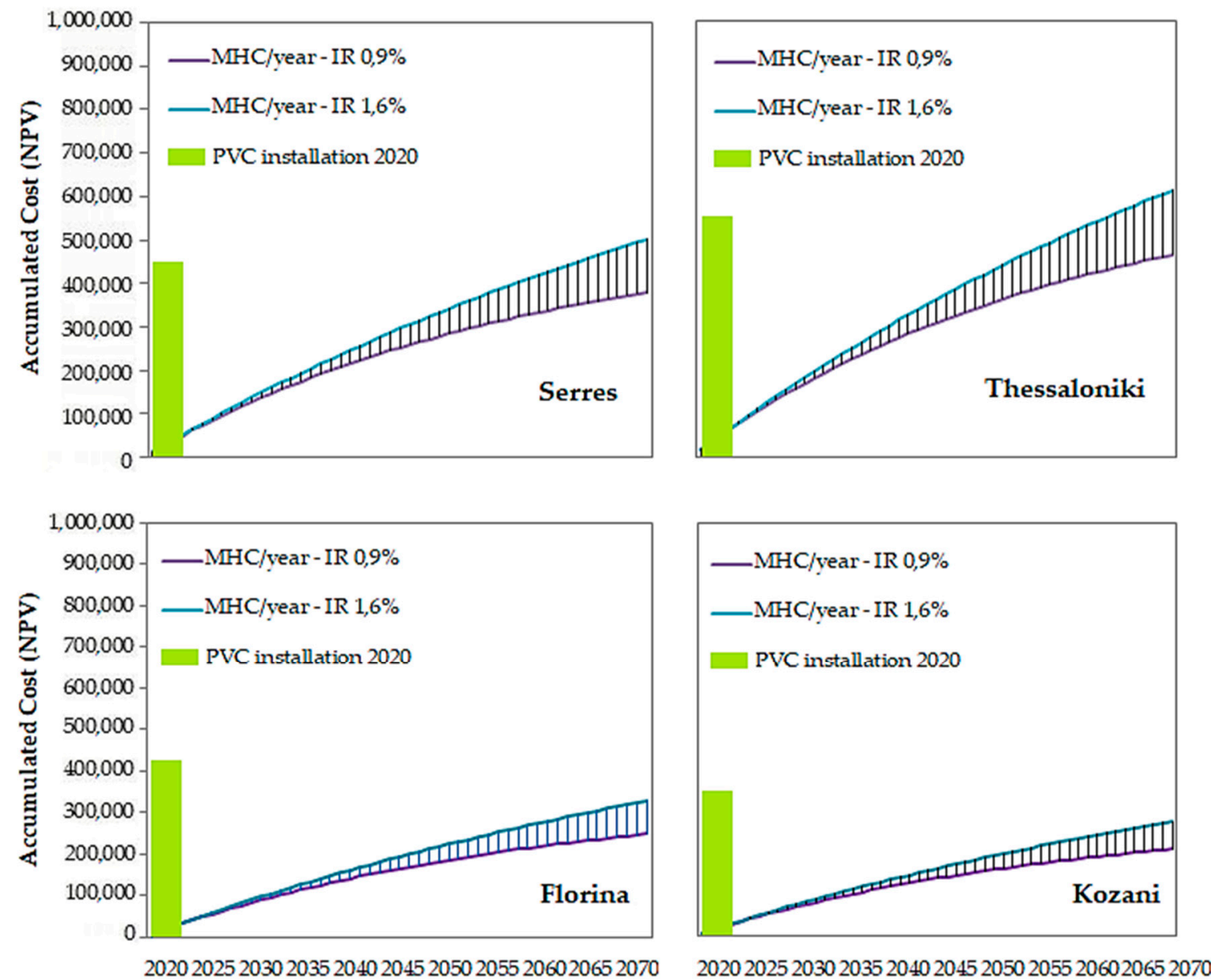

Figure 5. NPV graphs for MHC/year for 50 years for IR $0.9 \%$ and $1.6 \%$.

In the case of MHS, Serres and Thessaloniki showed that a possible PVC installation at the current time might be a reasonable option. In the case of Florina and Kozani, even with the case of a 1.6\% IR, the use of MHS is a cost-efficient option. It should be stated that the indirect cost of disturbances experienced by the residents of the cities (including lost time and road usage) is also vital in evaluating the total installation cost of PVC pipes. That way, the PVC pipe installation cost could increase to EUR 1 million, making the PVC installation a much less favorable option.

It is important to note that a combination of methods could be a significant advantage for decision makers, selecting among short-term and long-term solutions. More specifically, the choice of MHS for five years and in continuation with the installation of PVC for a long-term solution could be advantageous in case of a temporary low level of working capital. It could be an asset for local authorities in order to estimate and distribute future monetary plans to this direction, especially for smaller cities, as shown in Figure 5 even with higher values of IR.

Regarding the secondary part of the indirect social impacts on the community, in Table 3 these externalities are presented based on different controlling methods and the area of application. The non-stop nature of water flushing with maintenance interventions every month has a significant social cost in every area, though in Thessaloniki the economic damage could exceed the other values by a large margin. The second least economic option is the PVC installation, in which although the maintenance should disturb people only once throughout a 50-year period, this intervention would also close entire roadways for months. Finally, the application of MHS has the least economic impact on the local economy. For the application of MHS once per year, the economic cost is the lowest for every city, with losses between EUR 45,906 and EUR 802,969. 
Table 3. Indirect costs in euro from disturbance in a 50-year maintenance project based on different controlling methods.

\begin{tabular}{ccccc}
\hline Controlling Method & Kozani & Thessaloniki & Serres & Florina \\
\hline Water flushing & $2,121,665 €$ & $15,667,682 €$ & $2,379,757 €$ & $895,730 €$ \\
MHS/year & $108,735 €$ & $802,969 €$ & $121,963 €$ & $45,906 €$ \\
PVC installation & $265,208 €$ & $1,468,845 €$ & $223,102 €$ & $83,975 €$ \\
\hline
\end{tabular}

\section{Limitations of This Study}

The current approach targets only specific economic aspects and does not cover the whole procedure. This paper should be useful for a first cost-comparison estimation of the biocorrosion mitigation methodologies, and at a later stage a detailed life cycle costing or a techno-economical study should follow. Technical aspects regarding the "performance" of the biocorrosion mitigation measures were not studied. Material changes are to be expected over a service life of decades, especially if one of the two preventive measures is regularly applied to concrete surfaces. The durability of the material and also the long-term effectiveness should be considered. All these aspects should be considered when a local wastewater treatment facility agrees on a corrosion mitigation strategy.

\section{Conclusions}

In order to reach a sustainable maintenance treatment strategy in the sewer systems, a cost-comparison analysis was performed to examine biocorrosion mitigation methodologies. Spraying with MHS was considered to be the most cost-effective strategy to mitigate MIC. The main issue for local decision-makers is the time of decision-making. Today, the application of MHS is the most advantageous maintenance technique, based on direct and indirect economic assessment. Nevertheless, if the local authorities do not take into consideration the indirect social impacts, PVC installation is considered to be a cost-effective solution for larger cities. Furthermore, the least cost-efficient approach to the current biocorrosion problem in concrete sewers is water flushing, due to both direct and indirect economic parameters.

As future work, the authors will focus on the development of a universal financial assessment tool for the investigation of economic impacts related to corrosion controlling methods, integrating relevant actions of a circular economy model framework proposition [38]. Furthermore, future studies could focus on the installment of new liners inside old concrete pipes instead of the aforementioned biocorrosion mitigation strategies, since this could be considered to be a sustainable option in a circular economy as well.

Author Contributions: Conceptualization, G.F. and E.T.; methodology, G.F., E.T. and P.S.; software, E.T.; validation, G.F. and E.T.; formal analysis, G.F. and E.P.; investigation, G.F., E.T. and E.P.; resources, P.S.; data curation, G.F., E.T.; writing —original draft preparation, G.F. and E.T.; writing — review and editing, E.P. and P.S.; visualization, G.F. and E.T.; supervision, P.S.; project administration, P.S.; funding acquisition, P.S. All authors have read and agreed to the published version of the manuscript.

Funding: This research has been co-financed by the European Union and Greek national funds through the Operational Program Competitiveness, Entrepreneurship and Innovation, under the call RESEARCH-CREATE-INNOVATE (project code: T1EDK-02355-title 'Novel Coating Materials for Corrosion Protection of Sewer Network Pipes').

Conflicts of Interest: The authors declare no conflict of interest.

\section{References}

1. Islander, R.L.; Devinny, J.S.; Mansfeld, F.; Postyn, A.; Shih, H. Microbial Ecology of Crown Corrosion in Sewers. J. Environ. Eng. 1991, 117, 751-770. [CrossRef]

2. O'Dea, V. Understanding biogenic sulfide corrosion. Mater. Perform. 2007, 46, 11.

3. Wang, T.; Wu, K.; Kan, L.; Wu, M. Current understanding on microbiologically induced corrosion of concrete in sewer structures: A review of the evaluation methods and mitigation measures. Constr. Build. Mater. 2020, 247, 118539. [CrossRef] 
4. Grengg, C.; Mittermayr, F.; Ukrainczyk, N.; Koraimann, G.; Kienesberger, S.; Dietzel, M. Advances in concrete materials for sewer systems affected by microbial induced concrete corrosion: A review. Water Res. 2018, 134, 341-352. [CrossRef] [PubMed]

5. Zhang, L.; De Schryver, P.; De Gusseme, B.; De Muynck, W.; Boon, N.; Verstraete, W. Chemical and biological technologies for hydrogen sulfide emission control in sewer systems: A review. Water Res. 2008, 42, 1-12. [CrossRef] [PubMed]

6. Roghanian, N.; Banthia, N. Development of a sustainable coating and repair material to prevent bio-corrosion in concrete sewer and waste-water pipes. Cem. Concr. Compos. 2019, 100, 99-107. [CrossRef]

7. Fytianos, G.; Baltikas, V.; Loukovitis, D.; Banti, D.; Sfikas, A.; Papastergiadis, E.; Samaras, P. Biocorrosion of Concrete Sewers in Greece: Current Practices and Challenges. Sustainability 2020, 12, 2638. [CrossRef]

8. Karageorgos, P.; Latos, M.; Kotsifaki, C.; Lazaridis, M.; Kalogerakis, N. Treatment of unpleasant odors in municipal wastewater treatment plants. Water Sci. Technol. 2010, 61, 2635-2644. [CrossRef]

9. Bravo, L.; Ferrer, I. Life Cycle Assessment of an intensive sewage treatment plant in Barcelona (Spain) with focus on energy aspects. Water Sci. Technol. 2011, 64, 440-447. [CrossRef]

10. Gaterell, M.; Griffin, P.; Lester, J. Evaluation of Environmental Burdens Associated with Sewage Treatment Processes Using Life Cycle Assessment Techniques. Environ. Technol. 2005, 26, 231-250. [CrossRef]

11. Gallego, A.; Hospido, A.; Moreira, M.T.; Feijoo, G. Environmental performance of wastewater treatment plants for small populations. Resour. Conserv. Recycl. 2008, 52, 931-940. [CrossRef]

12. Hospido, A.; Moreira, M.T.; Feijoo, G. A comparison of municipal wastewater treatment plants for big centres of population in Galicia (Spain). Int. J. Life Cycle Assess. 2007, 13, 57. [CrossRef]

13. Ortiz, M.; Raluy, R.G.; Serra, L.M. Life cycle assessment of water treatment technologies: Wastewater and water-reuse in a small town. Desalination 2007, 204, 121-131. [CrossRef]

14. Sustainable Solutions Corporation, Life Cycle Assessment of PVC Water and Sewer Pipe and Comparative Sustainability Analysis of Pipe Materials Royersford, USA. 2017. Available online: https://www.uni-bell.org/files/Reports/Life_Cycle_Assessment_of_PVC_Water_and_Sewer_Pipe_and_ Comparative_Sustainability_Analysis_of_Pipe_Materials.pdf (accessed on 16 March 2020).

15. Kim, D.; Yi, S.; Lee, W. Life cycle assessment of sewer system: Comparison of pipe materials. In Proceedings of the 2012 World Congress on Advances in Civil, Environmental, and Materials Research (ACEN' 12), Seoul, Korea, 26-30 August 2012.

16. Gjorv, O.E.; Sakai, K. Concrete Technology for a Sustainable Development in the 21st Century; CRC Press: Boca Raton, FL, USA, 2003; pp. 332-340.

17. Æsøy, A.; Østerhus, S.; Bentzen, G. Controlled treatment with nitrate in sewers to prevent concrete corrosion. Water Supply 2002, 2, 137-144. [CrossRef]

18. Saleh, M.Y.; EL-Zahar, M.M.H.; Ashour, N.M.M. Application of Life Cycle Cost Analysis Method on Wastewater Treatment Plants In Egypt. In Proceedings of the Twenty-first International Water Technology Conference, IWTC21, Ismailia, Egypt, 28-30 June 2018.

19. Stein, D. Rehabilitation and Maintenance of Drains and Sewers; Ernst \& Sohn Wiley: Berlin, Germany, 2001; 804p.

20. UN-Habitat. State of the World's Cities 2008/2009-Harmonious Cities; UN-Habitat: Nairobi, Kenya, 2008.

21. XYLEM. WHITE PAPER Life Cycle Costs for Wastewater Pumping Systems June 2015. Available online: https://www.xylem.com/siteassets/support/tekniska-rapporter/white-papers-pdf/life-cycle-costslcc-for-wastewater-pumping-systems.pdf (accessed on 17 March 2020).

22. Concrete Pipe Associationof Australasia. Life Cycle Cost Analysis in Drainage Projects. Technical Brief. 2015. Available online: https://www.cpaa.asn.au/images/publications/technical_briefs/life\%20cycle\%20drainage. pdf (accessed on 17 March 2020).

23. Yoshida, H.; Christensen, T.H.; Scheutz, C. Life cycle assessment of sewage sludge management: A review. Waste Manag. Res. 2013, 31, 1083-1101. [CrossRef]

24. Abraham, D.M. Life Cycle Cost Integration for the Rehabilitation of Wastewater Infrastructure. Constr. Res. Congr. 2003, 1-9. [CrossRef]

25. Årskog, V.; Fossdal, S. Life-Cycle Assessment of Repair and Maintenance Systems For Concrete Structures. In Proceedings of the International Workshop on Sustainable Development and Concrete Technology, Beijing, China, 20-21 May 2014.

26. Tsagarakis, K.P.; Mara, D.; Angelakis, A.N. Application of Cost Criteria for Selection of Municipal Wastewater Treatment Systems. Water Air Soil Pollut. 2003, 142, 187-210. [CrossRef] 
27. Wu, L.; Hu, C.; Liu, W.V. The Sustainability of Concrete in Sewer Tunnel-A Narrative Review of Acid Corrosion in the City of Edmonton, Canada. Sustainability 2018, 10, 517. [CrossRef]

28. Noeiaghaei, T.; Mukherjee, A.; Mistri, A.; Chae, S.-R. Biogenic deterioration of concrete and its mitigation technologies. Constr. Build. Mater. 2017, 149, 575-586. [CrossRef]

29. Sydney, R.; Esfandi, E.; Surapaneni, S. Control concrete sewer corrosion via the crown spray process. Water Environ. Res. 1996, 68, 338-347. [CrossRef]

30. Nielsen, A.H.; Vollertsen, J.; Jensen, H.S.; Wium-Andersen, T.; Hvitved-Jacobsen, T. Influence of pipe material and surfaces on sulfide related odor and corrosion in sewers. Water Res. 2008, 42, 4206-4214. [CrossRef] [PubMed]

31. Sun, X.; Jiang, G.; Chiu, T.H.; Zhou, M.; Keller, J.; Bond, P.L. Effects of surface washing on the mitigation of concrete corrosion under sewer conditions. Cem. Concr. Compos. 2016, 68, 88-95. [CrossRef]

32. Crownmag. Innovative Coating Materials for Corrosion Protection of Sewer Network Pipes. Available online: http://crownmag.gr/en/ (accessed on 23 March 2020).

33. American Concrete Pipe Assocation. Least Cost Analysis. Resource 07-130 (06/07) 5M 2007. Available online: https://www.concretepipe.org/wp-content/uploads/2015/05/LCA-Brochure.pdf (accessed on 23 March 2020).

34. Rebitzer, G.; Hunkeler, D. Life cycle costing in LCM: Ambitions, opportunities, and limitations. Int. J. Life Cycle Assess. 2003, 8, 253-256. [CrossRef]

35. Mitsakis, E.; Stamos, I.; Grau, J.M.S.; Chrysochoou, E.; Iordanopoulos, P.; Aifadopoulou, G. Urban Mobility Indicators for Thessaloniki. J. Traffic Logist. Eng. 2013, 1, 148-152. [CrossRef]

36. Lemer, A. Life Cycle Costing: For the Analysis, Management and Maintenance of Civil Engineering Infrastructure. Constr. Manag. Econ. 2015, 33, 689-691. [CrossRef]

37. Wastewater Treatment Plants. Monitoring Database. Special Secretariat for Water. Ministry of Environment and Energy. Available online: http://astikalimata.ypeka.gr/Services/Pages/WtpViewApp.aspx (accessed on 24 March 2020).

38. Smol, M.; Adam, C.; Preisner, M. Circular economy model framework in the European water and wastewater sector. J. Mater. Cycles Waste Manag. 2020, 22, 682-697. [CrossRef]

(C) 2020 by the authors. Licensee MDPI, Basel, Switzerland. This article is an open access article distributed under the terms and conditions of the Creative Commons Attribution (CC BY) license (http://creativecommons.org/licenses/by/4.0/). 